\title{
PENERAPAN MODEL STUDENT TEAMS ACHIEVEMENT DIVISION \\ UNTUK MENINGKATKAN HASIL BELAJAR DAN KREATIVITAS BELAJAR EKONOMI
}

\author{
Dearlina Sinaga \\ Fakultas Keguruan Ilmu Pendidikan Universitas HKBP Nommensen \\ Email: dr.dearlina@gmail.com
}

\begin{abstract}
Abstrak: Penelitian ini bertujuan untuk meningkatkan hasil belajar dan kreativitas belajar ekonomi. Penelitian tindakan kelas ini menggunakan model pembelajaran kooperatif tipe Student Teams Achievement Division. Subjek penelitian adalah siswa kelas VIII-2 SMP Negeri-1 Pancur Batu yang berjumlah 38 orang. Data hasil belajar diperoleh lewat teknik tes, sedangkan data kreativitas belajar siswa lewat teknik observasi. Analisis data menggunakan metode analisis deskriptif kuantatif. Hasil penelitian menunjukkan bahwa hasil rata-rata pretes adalah 62,89 dimana hanya 37\% siswa yang memenuhi Standart Ketuntasan Belajar Minimal (SKBM). Setelah diadakan tindakan siklus I nilai rata-rata meningkat menjadi 75 dengan $71 \%$ siswa mencapai SKBM, pada siklus II nilai rata-rata meningkat menjadi 79 dengan $87 \%$ siswa memenuhi ketuntasan. Kreativitas juga mengalami peningkatan dari 59\% pada siklus I menjadi $78 \%$ pada siklus II. Dengan demikian, penerapan model STAD hasil belajar ekonomi meningkat sebesar 16\% dari siklus I ke II serta dapat meningkatkan kreativitas sebesar 19\% dari perbandingan siklus I dan siklus II.
\end{abstract}

Kata Kunci: model STAD, hasil belajar, kreativitas belajar

\section{THE APPLICATION OF STUDENT TEAMS ACHIEVEMENT DIVISION LEARNING MODEL TO IMPROVE THE LEARNING OUTCOMES AND CREATIVITY IN LEARNING ECONOMICS}

\begin{abstract}
The purpose of this research is to improve the learning outcomes and creativity in learning economics. This Classroom Action Research (CAR) was carried out using the model of Student Teams Achievement Division. The research subjects were students of class VIII-2 of SMP N 1 Pancur Batu with the total of 38 students. Data for outcomes analysis were collected through test and observation sheet. The results show that the average value of the pre-test is 62.89 in which only $37 \%$ of students meet the Minimum Standards Mastery Learning (SKBM). After the first cycle, the average value increases to 75 with $71 \%$ of students achieving SKBM, and after the second cycle, the average value increases to 79 which means $87 \%$ of students meet completeness. The creativity also increases from $59 \%$ in the first cycle to $78 \%$ in the second cycle. It can be concluded that the outcomes of economy learning has increased by $16 \%$ from cycle I to cycle II and the creativity has also increased $19 \%$ from the first cycle to the second cycle.
\end{abstract}

\section{Keywords: STAD Model, learning outcomes, learning creativity}

\section{PENDAHULUAN}

Pendidikan mempunyai peranan penting dalam kemajuan bangsa dan negara. Majunya pendidikan suatu bangsa memberi pengaruh kepada kualitas SDM-nya. Oleh karena itu, pembaharuan pendidikan harus selalu dilakukan untuk meningkatkan kualitas pendidikan suatu bangsa. Sebuah proses belajar, selain menuntut kreativitas guru juga dibutuhkan kesiapan siswa dalam pemebelajaran. Kesiapan tersebut akan membantu siswa menjadi lebih kreatif. Dengan demikian, sebuah proses belajar mengajar membutuhkan banyak dimensi kreativitas dalam interaksinya.

Ekonomi adalah sebuah materi yang terkait upaya pemenuhan kebutuhan manusia dengan sumberdaya yang terbatas. Konteks pembelajaran yang terkait dengan permasalahan sehari-hari manusia tentunya membutuhkan sebuah model pembelajaran kontekstual yang sederhana. Oleh karena itu, dicoba digunakan model STAD karena 
penggunaan model pembelajaan kooperatif tipe Student Teams Achievement Division (STAD) merupakan gaya pembelajaran sederhana, tetapi tepat dan relevan. Model itu digunakan karena dipandang representatif untuk menumbuhkembangkan kepekaan dan pola pikir aktif, kreatif, dan novatif untuk meningkatkan motivasi belajar siswa sekaligus meningkatkan pemahaman dan penguasaan materi serta konsep yang dapat diterapkan dalam kehidupan sehari-hari di lingkungan sekitar baik secara individu maupun kelompok.

Hasil beberapa penelitian juga menunjukkan adanya pengaruh positif model pembelajaran kooperatif terhadap prestasi belajar siswa seperti pada penelitian yang dilakukan Wawan dkk (2014) yang menunjukkan hasil bahwa pembelajaran kooperatif efektif dalam meningkatkan tingkat prestasi akademik siswa yang berpartisipasi serta dapat mempromosikan sikap positif siswa. Model Pembelajaran STAD merupakan bagian dari pembelajaran koorperatif. Model pembelajaran STAD merupakan pendekatan pembelajaran yang mengacu kepada belajar kelompok siswa dimana setiap minggu guru menggunakan prestasi verbal atau teks. Siswa dalam suatu kelas tertentu dipecah menjadi kelompok dengan anggota 4-5 orang,setiap kelompok heterogen, terdiri dari lakilaki dan perempuan, berasal dari berbagai suku, mmiliki kemampuan tinggi, sedang, dan rendah.

Wibowo dkk (2012:56) menyatakan bahwa STAD merupakan suatu metode genetik tentang pengaturan kelas dan bukan metode pembelajaran komprehensif untuk subjek tertentu, guru menggunakan pelajaran, dan materi mereka sendiri. Di pihak lain, Pratiwi dkk (2012:107) mengemukakan bahwa STAD adalah suatu metode pembelajaran kooperatif yang paling sederhana dan terdiri atas lima komponen utama yang meliputi presentasi kelas, tim, kuis, skor kemajuan individual, dan rekognisi tim.

Pada model pembelajaran STAD siswa ditempatkan dalam tim belajar beranggotakan 4-5 orang yang merupakan campuran menurut tingkat prestasi, jenis kelamin, dan suku. Guru menyajikan pelajaran, dan kemudian siswa bekerja dalam tim mereka memastikan bahwa seluruh anggota tim telah menguasai pelajaran tersebut. Kemudian, seluruh siswa diberikan tes tentang materi tersebut, pada saat tes ini mereka tidak diperbolehkan saling membantu.

Adapun lima komponen utama dalam STAD tersebut dikemukakan oleh Slavin (Trianto
(2010:76) sebagai berikut. (1) Penyajian Kelas (Class Presentation), penyajian kelas adalah penyampaian materi di awal pelaksanaan STAD. (2) Kelompok (Teams), kelompok atau tim terdiri atas 4 atau 5 orang siswa yang merupakan perwakilan representatif dari kelas berdasarkan prestasi akademik, jenis kelamin, dan ras atau kesukuan. (3) Tes (quizess), kira-kira satu atau dua mingggu setelah penyajian guru dan satu atau dua minggu diskusi kelompok, siswa diberi kuis atau tes individual. (4) Skor perkembangan individu, maksud untuk memperlihatkan pencapaian prestasi siswa apakah mencapai puncak (jika ia belajar keras) dan meraih yang terbaik dari nilai yang lalu.

Skor kelompok dihitung dengan membuat rata-rata skor perkembangan anggota kelompok, yaitu dengan menjumlah semua skor perkembangan yang diperoleh anggota kelompok dibagi dengan jumlah anggota kelompok.

Terkait dengan hakikat belajar Djamarah \& Zain (2006:38) menyatakan bahwa belajar pada hakikatnya adalah "perubahan" yang terjadi dalam diri seseorang setelah berakhirnya melakukan aktivitas belajar. Dalam belajar perlu adanya suatu interaksi, menurut Ibrahim dan Syaodih (2003:49) dalam suatu interaksi belajar interaksi ini bukan hanya terjadi antara siswa dengan guru, tetapi antara siswa dengan sumber (yaitu orang yang bisa memberi informasi), antara siswa dengan siswa lain, dan dengan media pelajaran. Sudjana (2005:92) berpendapat bahwa makin tinggi kemampuan siswa dan kualitas pengajaran, makin tinggi pula hasil belajar siswa.

Di pihak lain, Abdurrahman (2009:56) menyatakan hasil belajar adalah kemampuan yang diperoleh anak setelah melalui kegiatan belajar. Hasil belajar akan tercermin dari kepribadian siswa yang berupa perubahan tingkah laku, yang terwujud setelah mengalami proses pembelajaran. Sudjana (2010:97) menyatakan bahwa hasil belajar adalah kemampuan-kemampuan yang dimiliki siswa setelah iamenerima pengalaman belajarnya.

Dimyati \& Mudjiono (2010:43) menyatakan bahwa hasil belajar merupakan hasil dari suatu interaksi tindak belajar dan tindak mengajar. Dari sisi guru, tindak mengajar diakhiri dengan proses evaluasi hasil belajar. Dari sisi siswa, hasil belajar merupakan berakhirnya penggal dan puncak proses belajar. Hasil belajar dibedakan menjadi dampak pengajaran yaitu hasil yang dapat diukur seperti tertuang dalam angka rapor, 
angka dalam ijazah atau kemampuan meloncat setelah latihan dan dampak pengiring yaitu terapan pengetahuan dan kemapuan di bidang lain, suatu transfer belajar. Selain itu Keller dalam Abdurrahman (2012) memandang hasil belajar sebagai keluaran dari suatu sistem pemrosesan berbagai masukan berupa informasi.

Samion (2006) mengemukakan bahwa aktivitas belajar siswa memungkinkan didalam dirinya mengalami pola perubahan tingkah laku yang disadari dan dirasakan. Oka juga mengemukakan bahwa aktivitas siswa dalam proses belajar mengajar mempunyai peranan yang sangat penting dalam menunjang keberhasilan siswa. Sardiman (2011) menyatakan bahwa aktivitas merupakan prinsip atau asas yang sangat penting di dalam interaksi belajar-mengajar. Selain itu, Samion (2006) juga menyatakan bahwa aktivitas belajar siswa yang bersifat positif dimaksud adalah segala kegiatan yang mendukung keberhasilan belajar siswa, seperti; siswa harus belajar dengan tekun dan ulet, rajin meringkas atau menggaris bawahi hal-hal yang dianggap penting, mengulang materi pelajaran di rumah, memiliki buku catatan khusus untuk setiap mata pelajaran dengan kata lain catatan tidak dicampur adukan dalam satu buku, dan aktivitas lain yang dianggap mendukung proses pembelajaran di sekolah.

Terkait model pembelajaran kooperatif Solihatin \& Raharjo (2011) menyatakan belajar dalam kelompok kecil dengan prinsip kooperatif sangat baik digunakan untuk mencapai tujuan belajar, baik yang sifatnya kognitif, afektif, maupun konatif. Belajar bukan hanya sekedar kegiatan mencatat, menghapal dan mengerjakan tugas tetapi lebih dari itu belajar hendaknya mencerminkan tindakan atau perbuatan yang melahirkan ide atau gagasan dan mampu menghapal hal-hal yang ada semaksimal mungkin. Tindakan atau perbuatan tersebut dinamakan kreativitas.

Deporter dan Mike (2008) menyatakan bahwa kreatif adalah seseorang yang selalu mempunyai rasa ingin tahu, ingin mencoba-coba dan intuitif. Busan (2009) menyatakan bahwa kreativitas adalah kunci sukses dalam memunculkan ide-ide yang cemerlang dan orisinal. Windarwati (2006) menyatakan bahwa kreativitas merupakan sebagai pola berpikir atau ide yang timbul secara spontan dan imajinatif yang mencirikan hasil artistik, penemuan ilmiah, dan menciptakan secara mekanik dan lebih lanjut kreativitas meliputi hasil sesuatu yang baru bagi dunia ilmiah atau relatif baru bagi individunya.

Biasanya anak kreatif selalu ingin tahu, memiliki minat yang kuat, mempunyai kegemaran, dan aktivitas yang kreatif.Anak dan remaja yang kreatif biasanya cukup mandiri dan memiliki rasa percaya diri. Mereka lebih berani mengambil resiko (tetapi dengan perhitungan) dari pada anakanak pada umumnya. Artinya dalam melakukan sesuatu yang bagi mereka amat berarti, penting dan disukai, mereka pun tidak perlu menghiraukan kritik atau ejekan dari orang lain. Munandar (2009) mengatakan bahwa pribadi yang kreatif lebih terorganisasi pada tindakan. Siswa berbakat kreatif biasanya mempunyai rasa humor yang tinggi, dapat melihat masalah diri dari berbagai sudut tinjauan yang memiliki kemampuan untuk bermain ide, konsep atau kemungkinan-kemungkinan yang dikhayalkan.

Kreativitas tidak akan berkembang jika anak dapat melakukan sesuatu dengan satu cara berilah kegiatan yang tidak berstuktur dalam strukrur tertentu karena anak memerlukan batasan dan garis besar dalam mengerjakan suatu tugas, tetapi dalam batasan-batasan ini, hendaknya mereka dimungkinkan untuk membuat pilihan. Namun, dalam mengembangkan kreativitasnya, Munandar (2009) menyatakan bahwa dalam mengembangkan dan mewujudkan potensi kreatifnya, seseorang apakah dia anak atau orang dewasa dapat mengalami berbagai hambatan kendala atau rintangan yang dapat merusak bahkan mematikan kreativitasnya. Sumber kendala itu dapat bersifat internal, dan dapat bersifat eksternal. Jadi manfaat dari sumber belajar dalam pembelajaran sangat dibutuhkan, sehingga siswa dapat mencari sumber informasi yang relevan tentang materi pelajaran dan dapat meningkatkan kreativitas.

\section{METODE}

Penelitian dilakukan dengan pendekatan PTK (penelitian tindakan kelas) karena pendekatan tersebut memunyai tujuan untuk memperbaiki dan meningkatkan kualitas pembelajaran serta membantu memberdayakan guru dalam memecahkan masalah pembelajaran di sekolah (Muslich, 2010:10). Pada hakikatnya PTK mengupayakan tindakan perbaikan yang dilakukan secara terencana dan sistematis untuk memecahkan masalah pembelajaran kelas yang dihadapi oleh guru sehari-hari. Fokus penelitian adalah hasil belajar dan kreativitas belajar ekonomi siswa dengan 
model pembelajaran Student Teams Achievement Division (STAD).Penelitian dilaksanakan di SMP Negeri 1 Pancurbaru yang berjumlah 38 orang.

Dalam pelaksanaan PTK, setiap siklus terdiri dari 4 tahapan yaitu: (1) perencanaan tindakan, (2) pelaksanaan tindakan, (3) observasi tindakan, dan (4) refleksi. Rencana penelitian ini yang direncanakan selama dua siklus,tetapi tidak menutup kemungkinan akan dilanjutkan ke siklus berikutnya apabila belum memenuhi target penelitian (disesuaikan dengan waktu dan kondisi). Pengumpulan data dalam penelitian ini menggunakan tes dan observasi.

Kegiatan awal yang dilakukan adalah melakukan konsultasi dengan guru mata pelajaran Ekonomi, penyiapan perangkat pembelajaran seperti Rencana Pelaksanaan Pembelajaran (RPP), penentuan materi pelajaran sesuai dengan silabus dari Kurikulum KTSP, pembuatan skenario pembelajaran dengan menerapkan model pembelajaran STAD. Selain itu, juga disiapkan lembar kreativitas siswa untuk mengamati kreativitas yang dilakukan oleh siswa selama proses belajar dan selanjutnya menyusun tes hasil belajar yang akan digunakan sebagai alat untuk mengumpulkan data tentang hasil belajar siswa.

Data dikumpulkan dengan teknik tes dan pengamatan.Pengukuran tingkat atau persentase ketuntasan belajar siswa terhadap penguasaan materi pelajaran ekonomi digunakan rumus sebagai berikut Arikunto (2008):

$\mathrm{DS}=($ Skor angka yang diperoleh siswa $)$ : (jumlah skor maksimal) x 100\%

Selanjutnya untuk mengetahui ketuntasan secara keseluruhan dengan rumus:

$\mathrm{D}=\mathrm{x} / \mathrm{N} \times 100 \%$

Kriteria yang digunakan untuk mengukur hasil belajar siswa maupun hasil kreativitas siswa digunakan penilaian acuan patokan skala lima (Munandar, 2009) yang ditunjukkan pada Tabel 1.

Tabel 1. Penilaian Acuan Patokan (PAP)Skala Lima

\begin{tabular}{lll}
\hline Persentase & $\begin{array}{l}\text { Kriteria Hasil } \\
\text { Belajar Siswa }\end{array}$ & $\begin{array}{l}\text { Kriteria } \\
\text { Kreativitas }\end{array}$ \\
\hline $91 \%-100 \%$ & Sangat Tinggi & Sangat Kreatif \\
$71 \%-90 \%$ & Tinggi & Kreatif \\
$51 \%-70 \%$ & Sedang & Cukup kreatif \\
$31 \%-50 \%$ & Rendah & Kurang Kreatif \\
$10 \%-30 \%$ & Sangat Rendah & Tidak Kreatif \\
\hline
\end{tabular}

Tabel 2. Hasil Perolehan Nilai Tes Hasil Belajar Siswa Pretes dan Postes

\begin{tabular}{clccc}
\hline \multirow{2}{*}{ No. } & \multirow{2}{*}{ Interval Hasil Belajar } & Pretes & \multicolumn{2}{c}{ Postes } \\
\cline { 4 - 5 } & & 2 & - & Siklus I \\
\hline 2. & $10-30$ & 9 & 2 & - \\
3. & $31-50$ & 15 & 13 & 6 \\
4. & $71-90$ & 12 & 21 & 25 \\
5. & $91-100$ & - & 2 & 5 \\
6. & Rata-rata & 62,89 & 75,00 & 79,00 \\
7. & Tuntas & $37 \%$ & $71 \%$ & $87 \%$ \\
8. & Tidak Tuntas & $63 \%$ & $29 \%$ & $13 \%$ \\
9. & Kriteria Hasil belajar & Rendah & Tinggi & Tinggi \\
\hline
\end{tabular}

Tabel 3. Hasil Observasi Kreativitas Siswa

\begin{tabular}{lllll}
\hline $\begin{array}{l}\text { Interval } \\
(\%)\end{array}$ & Siklus I & & Siklus II & \\
\cline { 2 - 5 } & Jumlah siswa & Kriteria & Jumlah siswa & Kriteria \\
\hline $10-30$ & - & - & - & - \\
$31-50$ & 13 & Kurang kreatif & - & - \\
$51-70$ & 17 & Cukup kreatif & 7 & Cukup Kreatif \\
$71-90$ & 8 & Kreatif & 29 & Kreatif \\
$91-100$ & - & - & 2 & Sangat Kreatif \\
& 38 & & 38 & \\
\hline
\end{tabular}


Tabel 4. RangkumanHasil Observasi Kreativitas Siswa

\begin{tabular}{ccccc}
\hline No. & Observasi & Skor & Kreativitas (\%) & Kriteria Kreativitas \\
\hline 1. & Siklus I & 898 & $59 \%$ & Cukup \\
2. & Siklus II & 1184 & $78 \%$ & Kreatif \\
\hline
\end{tabular}

\section{HASIL DAN PEMBAHASAN Hasil}

Data hasil penelitian terdiri atas hasil pretes dan postes pada siklus I dan siklus II. Secara lengkap hasil tersebut ditunjukkan pada Tabel 2.

Observasi untuk melihat kreativitas belajar siswa dilakukan pada proses pembelajaran baik sebelum maupun selama proses pembelajaran berlangsung. Observasi dilakukan tiap pertemuan dan diakumulasikan untuk setiap siklusnya. Data hasil observasi siswa dari dua siklus selama kegiatan belajar mengajar berlangsung secara lengkap ditunjukkan pada Tabel 3.

\section{Pembahasan}

Berdasarkan hasil penelitian yag telah dilakukan, menunjukkan bahwa model pembelajaran kooperatif tipe STAD dapat meningkatkan hasil belajar siswa kelas VIII-2 SMP Negeri 1 Pancurbatu. Hal tersebut dapat dilihat dari tes hasil belajar yang menunjukkan bahwa hasil belajar lebih meningkat daripada sebelum menggunakan model pembelajaran yakni $62,89 \%$ menjadi $75 \%$. Kemudian akibat dilakukan perbaikan tindakan pada siklus II, hasil belajar juga menjadi lebih baik menjadi $79 \%$.

Untuk hasil belajar diukur dengan tiga indikator yakni tugas kelompok, pretes dan postes. Awalnya guru membentuk kelompok yang bersifat heterogen yang terdiri atas berbagai macam suku, jenis kelamin dan mempunyai tingkat prestasi yang berbeda. Selanjutnya, guru memberikan tugas kepada masing-masing kelompok. Kemudian guru memberikan pertanyaan kepada seluruh peserta didik dan pada saat menjawab pertanyaan tersebut tidak diperbolehkan saling membantu karena pada tahap ini peserta dapat memperlihatkan pencapaian prestasi tersendiri dan meraih nilai terbaik.Setelah itu, guru memberikan evaluasi tentang pencapaian nilai para kelompok maupun individual dan terakhir guru memberikan kesimpulan tentang materi pelajaran tersebut.

Melalui hasil tugas tersebut kemudian guru merefleksikan tindakan yang telah dilakukan selama proses belajar mengajar. Selain itu, guru memberikan umpan balik kepada siswa untuk menguji kemampuan siswa dalam menyerap pelajaran dengan memberikan tes, kemudian hasil tes tersebut dibandingkan dengan Kriteria Ketuntasan Minimal (KKM) dimana seorang siswa dinyatakan telah mencapai kompetensi jika siswa memperoleh skor 70 maka siswa tersebut dinyatakan lulus. Dan kelas dinyatakan tuntas jika dari keseluruhan siswa mendapat skor rata-rata kelas 70 atau $\geq 70 \%$ untuk mengetahui kemampuan pemahaman konsep siswa, dihitung rata-rata nilai dan ketuntasan belajarnya. Penelitian Astiti (2011) menemukan bahwa secara keseluruhan hasil belajar IPS siswa yang mengikuti pelajaran dengan menggunakan model pembelajaran kooperatif Tipe STAD dalam pembelajaran IPS lebih baik.

Slavin (2005:143-146) mengemukakan bahwa langkah-langkah model pembelajaran kooperatif tipe STAD terdiri atas presentasi kelas, kerja kelompok, mengerjakan kuis, skor kemajuan individual, dan rekognisi tim. Akan tetapi dalam penelitian ini, peneliti melakukan modifikasi dengan menambahkan kegiatan diskusi dan presentasi siswa. Dengan adanya diskusi dan presentasi siswa, akan meningkatkan kemampuan siswa untuk menyampaikan pendapatnya di dalam kelas. Kerja kelompok dan presentasi ini dilakukan untuk mengetahui kreativitas siswa terhadap materi yang disampaikan oleh guru. Selain itu, kuis yang dilaksanakan dapat mengetahui sejauh mana pemahaman siswa terhadap materi yang disampaikan oleh guru. Tahap terakhir dari pembelajaran kooperatif tipe STAD adalah penghargaan yang diberikan kepada kelompok. Poin-poin yang didapat dari mengerjakan lembar kuis digunakan untuk memberikan penghargaan kepada kelompok. Dengan diberikannya penghargaan kepada kelompok diharapkan dapat meningkatkan semangat dalam pembelajaran terutama pada mata pelajaran IPS.

Pemberian tindakan dalam penelitian ini berlangsung dalam dua siklus.Pada siklus pertama diberikan materi "mengidentifikasi bentuk 
pasar dalam kegiatan ekonomi masyarakat". Dari pengamatan proses belajar, persoalan yang ditemukan antara lain siswa belum mengerti pembelajaran dengan model STAD. Hal tersebut terjadi karena guru sendiri kurang memberikan pemahaman tentang model ini, sehingga yang terjadi adalah ketika guru melakukan pengorganisasian siswa, masih banyak siswa yang membuat keributan di kelas dan mengganggu siswa yang lain. Pada siklus pertama ini juga ditemukan masih banyak siswa yang diam dan hanya menunggu pertanyaan yang diajukan guru.

Kegiatan observasi digunakan delapan indikator yakni: rasa ingin tahu, bertanya, memberi ide, mampu melihat masalah, pemecahan masalah, memunyai rasa humor, dan memunyai daya imajinasi. Hasil observasi kreativitas siswa tergolong cukup karena belum seluruh siswa memberi tanggapan. Terkadang juga siswa memberikan pendapat yang sama dengan siswa lainnya karena sifat internal pribadi siswa yaitu kurang berani mengeluarkan pendapat.

Mengacu pada permasalahan di siklus pertama, kemudian dibuatlah perencanaan untuk melakukan siklus kedua, ditemukan bahwa dalam pelaksanaan tindakan, masalah yang dihadapi pada siklus pertama menjadi berkurang. Pada siklus kedua, terlihat bahwa motivasi siswa untuk belajar IPS menjadi meningkat, hal ini ditunjukkan dengan siswa sudah mulai aktif berdiskusi dengan teman kelompoknya, kemudian mulai aktif bertanya pada hal-hal yang belum diketahuinya, termasuk aktif dalam memberikan tanggapan pada presnetasi yang dilakukan oleh kelompok lain.

Guru berupaya untuk memberikan penjelaskan yang mudah dipahami oleh siswa dan lebih meningkatkan kreativitas siswa agar berani mengemukakan pendapat serta memberikan tanggapan dan jawaban dari suatu permasalahan. Hal ini sejalan dengan yang ditemukan Efran (2010) dengan judul strategi pembelajaran Tipe STAD terhadap kreativitas siswa pada mata pelajaran ekonomi kelas XI di SMA Negeri 3 Palembang, bahwa selain hasil belajar maka kreativitas siswa juga dapat meningkat.

Dari hasil pengamatan pada siklus I dan siklus II secara keseluruhan dapat dikatakan bahwa pembelajaran dengan menggunakan model pembelajaran koopertif tipe STAD pada siswa kelas VIII-2 SMP terjadi peningkatan kreativitas dengan baik dari 59\% menjadi 75\%. Namun, jika diamati lebih cermat dari 38 orang siswa di kelas VIII-2, jika pada siklus I, masih terdapat 13 orang siswa yang kurang kreatif pada siklus II tidak ditemukan lagi. Demikian juga, jika pada siklus I beluam ada siswa yang sangat kreatif pada siklus II sudah ada 2 orang siswa yang sangat kreatif.

Kelebihan model kooperatif tipe STAD yang terdapat pada penelitian ini selama pembelajaran adalah sebagai berikut. Pertama, siswa lebih tertarik, perhatian, dan senang dalam pembelajaran karena adanya kerjasama antar kelompok dan penghargaan bagi kelompok sehingga materi dapat tersampaikan dengan baik. Kedua, Kreativitas meningkat karena kesediaan siswa yang berprestasi dan aktif untuk mempresentasikan hasil diskusi kelompoknya, juga menjawab pertanyaan yang diajukan oleh kelompok lain. Ketiga, motivasi yang diberikan guru, dengan memberikan kesempatan serta kepercayaan kepada siswa yang pasif dan kurang berprestasi untuk dapat mempresentasikan serta mengajukan pertanyaan sekaligus menjawab pertanyaan, membuat suasana kelas lebig bervariasi dan tidak lagi didominasi hanya oleh siswa berprestasi.

Namun, selain kelebihannya terdapat juga kelemahan ketika mengerjakan model STAD. Kelemahan yang muncul selama proses pembelajaran dengan menggunakan model kooperatif tipe STAD adalah sebagai berikut. Pertama, guru kesulitan dalam mengatur waktu karena kelompok yang terdiri dari 4-5 orang sehingga presentasi siswa kurang maksimal. Akibatnya tidak semua siswa di kelas VIII-2 mengalami peningkatan hasil belajar. Kedua, tidak setiap siswa punya kesempatan untuk menyampaikan pendapatnya ketikapresentasi di kelas. Kedua, pada pertemuan pertama siklus I, banyak siswa yang memilih untuk berkelompok dengan teman dekatnya sendiri, sehingga banyak siswa yang kurang berprestasi berkelompok dengan siswa yang kurang berprestasi juga. Ketiga, dalam persentasi kelompok, siswa yang berprestasi masih dominan dalam menjawab atau memberikan pertanyaan, namun guru belum dapat mengatasi hal tersebut, sehingga presentasi dan tanya jawab menjadi didominasi oleh siswa yang berprestasi.

Penjelasan di atas telah membuktikan bahwa model STAD dapat meningkatkan hasil belajar dan kreatifitas belajar pada siklus II, oleh karena itu penelitian ini dapat dihentikan dan tidak perlu dilanjutkan lagi ke siklus berikutnya. Hasil penelitian ini juga didukung oleh peneliti terdahulu yang 
ditemukan Arjani(2014) hasil belajar mengalami peningkatan di siklus $\mathrm{k}-2$, dan tidak dilanjutkan lagi pada siklus berikutnya, juga hasil penelitian yang dilakukan Tambun dkk(2013) tentang model pembelajara STAD menunjukkan bahwa hasil belajar IPS Terpadu siswa setelah dilakukan penerapan Model Pembelajaran Kooperatif Tipe STAD menunjukan bahwa rata-rata seluruh hasil belajar siswa kelas VIII SMP Negeri 3 Poigar mengalami peningkatan. Hal ini ditunjukkan dengan adanya peningkatan hasil rata-rata persentase lembar observasi hasil belajar setiap siklus, yaitu pada siklus I hasil belajar siswa sebesar $70 \%$ dengan ketuntasan 14 siswa, untuk siklus II sebesar 90\% dengan ketuntasan 18 siswa, dan tidak dilanjutkan ke siklus berikutnya.

Dengan demikian mengacu pada hasil penelitian ini, maka dapat disarankan bahwa pembelajaran dengan menggunakanmodel pembelajaran kooperatif tipe STAD perlu diberlakukan di SMP Negeri 1 Pancurbatu. Dari hasil penelitian ini juga sekaligus menjawab pertanyaan penelitian bahwa ada peningkatan hasil belajar dan kreativitas belajar siswa.

\section{SIMPULAN}

Berdasarkan hasil penelitian dan pembahasan yang telah dikemukakan terdapat peningkatan hasil belajar ekonomi dengan menerapkan model pembelajaran Student Teams Achievement Division. Pada siklus I diperoleh nilai rata-rata 75 dan persentase ketuntasan belajar siswa sebesar $71 \%$ selanjutnya pada siklus II diperoleh nilai rata-rata 79 dengan persentase sebesar $87 \%$ jumlah siswa yang telah mencapai standart kelulusan belajar. Peningkatan nilai kemampuan siswa antara siklus I ke siklus II adalah 4,00 untuk hasil belajar ekonomi dengan peningkatan persentase sebesar 16\%. Melalui observasi juga ditemukan kreativitas siswa juga menunjukkan peningkatan yang signifikan antara siklus I yaitu 59\% menjadi $78 \%$ pada siklus II. Peningkatan yang ditunjukkan sebesar 19\%. Melalui temuan ini disarankan agar guru sebaiknya menggunakan model pembelajaran ini karena melalui pembelajaran kooperatif siswa yang heterogen dapat saling berinteraksi dengan saling melengkapi sehingga bukan hanya hasil belajarnya yang meningkat tetapi juga kreativitas belajarnya.

\section{UCAPAN TERIMA KASIH}

Ucapan terima kasih disampaikan kepada Kepala Sekolah dan para guru di SMPN 1 Pancurbaru yang telah membantu proses penelitian ini. Terima kasih juga diucapkan kepada Reviewer dan Redaktur Jurnal Cakrawala Pendidikan yang telah memberi saran dan masukan perbaikan artikel ini. Harapannya, artikel ini bermanfaat bagi upaya pengembangan proses pembelajaran di sekolah.

\section{DAFTAR PUSTAKA}

Abdurrahman, Mulyono. 2012. Anak Berkesulitan Belajar: Teori, Diagnosis, dan Remidiasinya. Jakarta : Rineka cipta.

Arikunto, Suharsimi, Suharjono, dan Superdi. 2008. Penelitian Tindakan Kelas. Jakarta: Bumi Aksara

Arjani, Ni Putu Sinta. 2014. "Penerapan Model Pembelajaran Kooperatif Tipe STAD Berbantuan Media Komputer dalam Meningkatkan Aktifitas dan Hasil Belajar Siswa Kelas X.2 Pada Mata Pelajaran Geografi SMA Negeri 1 Tegallalang, Kabupaten Gianyar Tahun Pelajaran 2012/2013”. Ejurnal.Unhiksa.ac.idindex.phpjj.

Astiti, Ni Wayan, Ni. 2011. "Pengaruh Model Pembelajaran Kooperatif Tipe STAD dan Motivasi Prestasi Terhadap Hasil Belajar IPS Siswa Kelas VII SMP NEGERI 2 Semarapura". Jurnal Pascasarjana UNDHIKSA.

Busan, Tony. 2009. Mind Map. Terjemahan Purwoko, Jakarta: Gramedia Pustaka Utama

Deporter, Bobby dan Mike, Hernacki. 2008. Quantum Learning. Terjemahan Abdulrrahman Alwiyah. 2008. Bandung: Mizan Pustaka.

Djamarah, Syaiful Bahri \& Zain, Aswan. 2006. Strategi Belajar Mengajar. Jakarta: Rineka Cipta.

Dimyati dan Mudjiono. 2010. Belajar dan Pembelajaran. Jakarta: Rineka Cipta. 
Efran. 2010. "Strategi Pembelajaran Resource Based Learning terhadap Kreativitas Siswa Pada Mata Pelajaran Ekonomi di SMA Negeri3 Palembang". Syu3f.blogspot/2010/ strategi pembelajaran. (diakses 5 Maret 2014)

Ibrahim, R. \& Syaodih S, Nana. 2003. Perencanaan Pengajaran. Jakarta: Pusat Perbukuan Departemen Pendidikan \& Kebudayaan dan Rineka Cipta.

Munandar, Utami. 2009. Pengembangan Kreativitas Anak Berbakat. Jakarta: Rineke Cipta.

Muslich, Masnur. 2010. Melaksanakan PTK Itu Mudah. Jakarta ; PT Bumi Aksara.

Pratiwi, Dyah, dkk. 2012. Penerapan Metode STAD dengan Media Benda Konkret Dalam Peningkatan Pembelajaran Pecahan Siswa Kelas IV Sekolah Dasar. Jurnal Pendidikan. Volume 5, No. 4, 2016 http:// jurnal.fkip.uns.ac.id/index.php/pgsdkebumen/article/view/2257/1643 (diakses 6 Maret 2014).

Samion, Ar. 2006. "Pengaruh Disiplin Mengajar Guru Terhadap Aktivitas Belajar Siswa Sekolah Menengah Pertama Etika Pontianak". Jurnal No. 1/XXV/2006. STKIP PGRI Pontianak.

Sardiman, A.M. 2011. Interaksi dan Motivasi Belajar-Mengajar. Jakarta: PT RajaGrafindo Persada.

Slavin, Robert E. 2005. Cooperative Learning. Bandung. Nusamedia.
Trianto. 2010. Model Pembelajaran Terpadu. Surabaya: Bumi Aksara

Solihatin, Etin \& Raharjo. 2011. Cooperatif Learning Analisis Model Pembelajaran IPS. Jakarta : PT Bumi Aksara.

Sudjana, Nana. 2010. Penilaian Hasil Proses Belajar Mengajar. Bandung: PT. Remaja Rosdakarya.

Tambun, Fitria, Johny Manaroinsong, dan Fienke Rumawir, 2013. "Penerapan Model Pembelajaran Kooperatif Tipe STAD dalam Meningkatkan Hasil Belajar Siswa Pada Mata Pelajaran IPS Terpadu Di Kelas VIII SMP Negeri 3 Poigar". Jurnal Pendidikan Ekonomi, Vol 1, No 5 (Diakses 16 Juli 2013)

Wawan, et al, 2014. "Eksperimantasi Model Pembelajaran Kooperatif tipe STAD”. Jurnal Elektronik Pembelajaran Matematika. Vol. 2, No.8, hal 791-803, Oktober 2014

Wibowo, Rahmat, dkk. 2012. "Penerapan Model Kooperatif Tipe STAD dalam Peningkatan Pembelajaran Bangun Datar pada Siswa Kelas V SD". Jurnal Pendidikan. Volume 5, No.1.online: http://jurnal.fkip. uns.ac.id/index.php/pgsdkebumen/article/ view/2058/1498 (diakses 6 Maret 2014).

Windarwati, Sri. 2006. "Strategi Meningkatkan Kreativitas Melalui Penerapan Pendekatan Resource Based Learning". Jurnal Pembelajaran, 2:1:29. Online: http://jurnal. pdoo.lipi.go/admin/jurnal/21062841.pdf. (diakses 6 Maret 2014). 